The

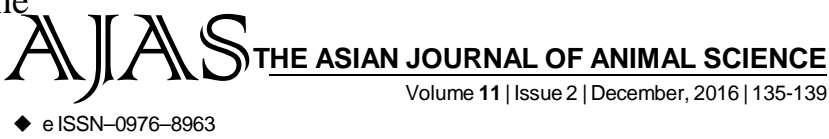

DOI : 10.15740/HAS/TAJAS/11.2/135-139

Visit us | www.researchjournal.co.in

\title{
A chromosomal investigation of three species of Papilio (Papilionidae:Lepidoptera)
}

MEENU SADHOTRA

AUTHOR FOR CORRESPONDING :

\section{MEENU SADHOTRA}

Department of Zoology, Govt.

College for Women, Parade,

JAMMU (J\&K) INDIA

Email: meenusadhotrasharma@

gmail.com

\begin{abstract}
Lepidoptera is one of the largest orders of the class Insecta which includes butterflies and moths and is economically, biologically and aesthetically an important order. Chromosome structure and size are of great significance in karyological studies and have relevance to evolution, speciation and chromosome organization. Karyotypic studies in Lepidoptera has been a difficult task due to small dot- like chromosomes of similar sizes. The chromosome cytology of Indian Lepidoptera is very much limited. Chromosome studies in three species of butterflies (Papilio polytes, Papilio demoleus, Papilio glaucus) revealed 60 as diploid chromosome number.
\end{abstract}

KEY WORDS....... Chromosome, Diploid chromosome number

HOW TO CITE THIS ARTICLE - Sadhotra, Meenu (2016). A chromosomal investigation of three species of Papilio (Papilionidae:Lepidoptera). Asian J. Animal Sci., 11(2): 135-139. DOI : 10.15740/ HAS/TAJAS/11.2/135-139.

ARTICLE CHRONICLE - Received : 20.07.2016; Revised : 01.11.2016; Accepted : 16.11.2016 